\title{
INNOVATIONS IN THE SYSTEM OF LOCAL SELF-GOVERNMENT IN POLAND IN THE PROCESS OF SHAPING MODERN ADMINISTRATION
}

\author{
Barbara Bonisławska \\ European University of Information Technology and Economics in Warsaw, Warsaw, Poland \\ e-mail: bbonislawska@wp.pl
}

Received: 03 March, 2020 Accepted: 20 June, 2020 Published: 25 August, 2020

\begin{abstract}
:
In the process of shaping a modern administration, the key issue is to build a rational political basis and activities of this administration. Self-government administration occurs in individual territorial division units, i.e. in communities, districts and voivodeships. This administration is formed on the basis of decentralization of public authority and independence of exercising power by particular local government units. The competence of this administration is to undertake public matters of local and regional dimension in terms of meeting the collective needs of local government communities. These matters are dealt with by local government authorities (community-district-voivodeship) and an extensive administrative system of local government organizational units.
\end{abstract}

Key words: community, district, head of a district, mayor/president, marshal, local community

JEL classification: H10; H50; H70

Citation:

Bonislawska, B. 2020. Innovations in the system of local self-government in Poland in the process of shaping a modern administration. Access journal, ACCESS Press, 1(2): 122-130. https://doi.org/10.46656/access.2020.1.2(4)

\section{INTRODUCTION}

The issue of the multilevel territorial division of the state in Poland, which has been discussed for many years in the process of democratization of the state, was determined by the Act of 24 July 1998 on the introduction of the basic a three tier territorial division of the state which results from the very title of the Act. The units of the basic three-tier territorial division of the state are: communities, districts and voivodeships. The basic three-tier division of the country's territory was introduced on 1 January 1999. The Act passed by the parliament fulfilled the constitutional footnote of Article 15 (2) on the creation of the division of the state. At the same time, the provision indicates the premises to be followed in making the territorial division, i.e. to take into account social, economic or cultural ties and to ensure that territorial units are able to perform public tasks. (Zieliński, 2004, p.19).

Poland is divided into 16 voivodeships, 314 districts and 2477 communities (including 302 urban communities, 66 towns with district rank, 642 rural and urban communities and 1533 rural communities (Ministry of the Interior and Administration, 2020). 


\section{System of community self-government}

Community is a basic self-government commune. It is granted by Article 164(1) of the Constitution of the Republic of Poland, which states "The community (gmina) shall be the basic unit of local government". It does not exclude the possibility to create other self-government units on the local or regional level, which may be established by law (Zieliński, 2013, p. 261).

The Act on local self-government stipulates that ,the inhabitants of a community form self-government commune by law" (Article1) and that:

- community fulfills public tasks on its own behalf and responsibility

- community has legal personality

- independence of a community is under legal protection (Art. 2).

The bodies of a community are: community council - decision-making body and a head (mayor, president of town) - executive body. Rules and procedures for conducting elections of community council, and a head (mayor, president) are defined by separate Acts. (Article 11a).

The activity of community bodies is public. The publicity can be limited only by legal Acts. Publicity of activities of community bodies includes citizens' rights for information, access to sessions of the community council and its commissions as well as access to documents from performing public tasks including minutes of community and community commissions sessions (Article 11b). Rules on access and using documents are described in a community statute. The term in the office of a community council lasts 5 years from the election day. (Article 5)

The Act in Article 18 defines all the competencies of a commune.

The community council controls the activity of mayor, community organizational units and community auxiliary units and for this purpose, in accordance with the Act, it appoints an audit committee. Community council also deals with complaints against the activities of a mayor and community organizational units and citizen's applications and petitions. A commission of complaints, applications and petitions is appointed for this purpose. The audit committee gives opinion on budget implementation of a community and applies to the community council whether to grant or not a discharge to a mayor. The proposal for discharge is a subject to an opinion of the Regional Audit Chamber (Article 18a, Article 18b)

Mayor implements resolutions of the community council and tasks of the community stated by law. Mayor's tasks include: preparation of drafts of the community council, preparation of development programs according to the procedures defined in regulations on principles of the development policy, principle of manner of resolutions implementation, managing community property, budget implementation and hiring and dismissal of managers of organizational units of a community. While performing community's own tasks, mayor responds exclusively to the community council. (Article 30) 
Mayor manages community's current affairs and represents it externally, prepares operational plans of flood protection as well as announces and cancels emergency services and flood alarm. If there is no other possibility to remove the direct danger for people's life and property, the mayor may order an evacuation form the directly threatened areas. In case of state of emergency mayor may act according to separate regulations (Article 31, 31a, 31b).

According to the Act of 20 June 2002 on direct election of mayor and president of town, mayor / president is elected in general, equal and direct vote by a secret ballot (Article 2)

\section{Scope of activity and tasks of a community.}

Scope of activity includes mainly all public matters with a local importance not reserved by law for other bodies. Satisfying collective needs of a community is one of community's own tasks. Moreover, community's own tasks mainly concern: spatial order, property management, nature and environment protection, water management, community roads, streets, bridges, squares, traffic organization, water pipes and water supply, sewage, removing and treatment of urban waste water, cleaning, maintaining order, sanitation, landfills and disposal of urban wastes, supply of electricity, heat and gas, activity concerning telecommunication, local public transport, health care, social assistance - including care centers, nurseries and family support, foster custody system.

Community is also responsible for: community building, state education, culture (community libraries and other institutions in charge of culture and protection and care of monuments), physical culture and tourism, including recreational areas and sports facilities, markets and fair halls, municipal greenery and trees, municipal cemeteries, public order and safety as well as fire and flood protection, including maintaining fire protection warehouse, community and public utility facilities, administrative facilities, profamily policy, including ensuring health, social, medical and legal care for pregnant women, support and promotion of self-government ideas, including creating conditions for the activity and development of auxiliary units, implementation of programs to stimulate civic activity, promotion of the community, cooperation and activity for non-governmental organizations, cooperation with local and regional communities from other countries. Tasks of government administration may also be performed by the community on the basis of an agreement with the bodies of this administration (Article 7). Good workers, who able to work and deal with problems effectively, negotiate, offer the highest quality of service, etc., are sought-after in the labour market (Stemplewska, 2020, p. 154).

\section{System of a self-government of a district}

District is a territorial self-government unit, called district self-government. According to the Constitution of the Republic of Poland (Article 164 (2)) and Act of 5 June 1998 on district self-government (Article 1 (1)), district self-government is a local self-government commune. This commune is by law formed by district 
citizens who live in a specific territory. Territory and citizens of a district are therefore an essential factor to create local self-government commune. (Zieliński, 2013, p. 303)

According to the Act on district self-government - District carries out public tasks defined by the Acts on its own behalf and responsibility. District has legal personality. Independence of a district is a subject to judicial protection and system of a district is defined in its statute (Article 2). District residents make decisions by general election (district elections and referendum) or through district bodies (Article 8.1)

District bodies are: district council (decision-making body) and district board (executive body).

Activity of district bodies is public. The publicity can be limited only by legal Acts (Article 8a. 1.) Publicity of activities of district bodies includes citizens' rights for information, access to sessions of the district council and its commissions as well as access to documents from performing public tasks including minutes of district bodies and district council commissions. Rules on access and using documents are described in a district statute (Article 8.3). District council is a decision-making and control body, subject to provisions of district referendum. The term in the office of a council lasts 5 years from the election day. Councilors are elected in general elections. The rules and procedure for conducting elections to the district council are defined in a separate act (Article 9).

Competences and tasks of the district council are defined in Article 12 of the Act on District SelfGovernment. Resolutions of the district council and board are adopted by a simple majority of votes in the presence of at least half of the statutory composition of the council (board), in an open voting.

District council controls the activity of the board and district organizational units. For this purpose it appoints an audit committee. The audit committee gives its opinion on implementation of district budget and applies to the district council whether to grant or not a discharge to the board. The proposal for discharge is a subject to an opinion of the Regional Audit Chamber. The district council deals with complaints against the activities of the board and district organizational units and citizen's applications and petitions and for this purpose it appoints a committee of complaints, applications and petitions (Article 16, 16a).

District board is an executive body of a district. The district board is composed of Starosta (head of a district) as a chairman, vice Starosta and other members. Non-Polish citizen may not be a member of a district board (Article 26)

District board implements the resolutions of the district council and tasks of the district stated by law. The tasks of a district include in particular:

- preparation of drafts of council resolutions;

- implementing council resolutions;

- preparation of development programs according to the procedures defined in regulations on the principles of conducting development policy;

- managing the property of the district; 
- implementation of the district budget;

- hiring and dismissal of managers of organizational units of a district,

- enacting the organizational regulations of Starost (the head of a district).

In carrying out the tasks, the district board is responsible only to the district council. The internal organization and working manner of the board is defined by statute of the district. The statute of the district is published in the voivodeship official journal. (Article 32)

The board carries out the tasks of a district with the support of the Starost Office (the office of the head of a district) and district organizational units, including the district employment office.

The heads of district services, inspections and guards carry out the tasks and competences defined in the Acts and are supported by organizational units - police commands and inspectorates.

Organizational units constituting the auxiliary units of managers of district services, inspections and guards may be created, restructured and liquidated by a voivode, upon request of a Starost (head of district), with an opinion of a competent head of a combined service, inspection or voivodeship guard. Organizational units (except for organizational units of the Police) are budgetary units of a district.

Specific terms and conditions or rules for appointing, dismissing and procedures for employment and dismissal of managers and employees of district services, inspections and guards are defined in separate acts. The district combined administration comprises:

1) Starost's Office (Head of district office);

2) district employment office, an organizational unit of a district;

3) organizational units constituting the auxiliary units of heads of district services, inspections and guards. (Articles 33, 33a, 33b)

Starost (head of a district) organizes the work of a district board and district office, manages the current affairs of a district and represents the district outside. The Starost (head of a district) prepares a flood protection operational plan, announces and cancels emergency services and flood alarm (Article 34.1. and 1a). The organization and functioning of a district office is defined in the organizational regulations. The Starost (head of a district) is the head of a district office, district employees, district organizational units and district services, inspections and guards (Article 35). A security and order committee, hereinafter referred to as "the committee", is established in order to carry out the tasks of the Starost (head of a district) with regard to the authority over district services, inspections and guards and tasks specified in the Acts on public order and safety of citizens (Article 38a.1.)

\section{Scope of activity and tasks of a district}


District carries out the supra-community public tasks specified in Article 4 of the Act on district selfgovernment.

At the same time, district's own tasks are presented doctrinally and grouped on the basis of 5 cases:

- extended social infrastructure,

- extended technical infrastructure,

- public security and order of citizens in a supra-community dimension,

- organizational activity aimed at solving local problems (Chmaj 2007, pp. 105-106.)

The public tasks of the district also include ensuring that the tasks and competences of district heads of services, inspections and guards specified in the Acts are fulfilled (Article 4.).

\section{System of self-government of a voivodeship}

In the voivodeship, government administration is performed by specific entities, as indicated in the Act of 23 January 2009 on the voivodeship and government administration in the voivodeship and other Acts. These acts not only indicate these entities, but also refer to the Acts which create entities of government administration. Moreover, it should be remembered that the administration in a voivodeship is, to a large extent, exercised as a decentralized authority by self-government units, apart from the tasks of government administration. Thus, the public administration system in a voivodeship is composed of two subsystems: government and self-government administration (Zieliński 2013, p.193).

The inhabitants of the voivodeship form a regional self-government community by law. Self-government administration in the voivodeship is united in one office and under one superior. Under Article 4.1 of the Act on Self-Government of the voivodeship, the scope of activities of the self-government of a voivodeship does not interfere with the independence of a district and a community. The voivodeship self-government bodies are not supervisory or control bodies for a district and community and are not higher in administrative proceedings.

The structure of a voivodeship as a self-government unit is defined in the voivodeship's statutes adopted after consultation with the Prime Minister. The statutes and amendments thereto are published in the voivodeship official journal. The voivodeship self-government performs public tasks specified by the statutes on its own behalf and on its own responsibility, has at its disposal the voivodeship property, runs financial management based on the budget. The voivodeship has legal personality and the voivodeship's independence is subject to judicial protection.

The voivodeship self-government bodies are: Sejmik of the voivodeship (voivodeship assembly) - the decision-making body, the voivodeship board - the executive body.

Activity of voivodeship bodies is public. The publicity can be limited only by legal Acts. Publicity of activities of voivodeship bodies includes citizens' rights for information, access to sessions of the 
voivodeship assembly (Sejmik) and its commissions as well as access to documents from performing public tasks including minutes of voivodeship bodies and voivodeship council commissions.

Voivodeship board is an executive body of a voivodeship. Voivodeship board consists of 5 persons, they are: Marshal of the voivodeship (marszałek) as a chairman, one or two vice-marshals and other members.

Three months after a competent electoral authority announces of the election results, the voivodeship assembly (Sejmik) elects the voivodeship board, including the provincial marshal and no more than 2 vicemarshals. The voivodeship assembly (Sejmik) elects the voivodeship marshal by an absolute majority of votes of the statutory composition of the assembly (Sejmik), in a secret ballot. The marshal, vice-marshals and other members of the voivodeship board may be elected from outside the composition of the voivodeship assembly (Sejmik).

Every year till the 31st May the voivodeship board presents to the voivodeship assembly (Sejmik) a report on the condition of the voivodeship. The report includes a summary of the activities of the voivodeship board in a previous year, in particular the implementation of policies, programs and strategies, resolutions of the voivodeship assembly (Sejmik) and a participatory budget.

The tasks of the voivodeship board are defined in the Act on voivodeship self-government. The rules and mode of operation of the voivodeship board are defined in the voivodeship statute.

The voivodeship assembly (Sejmik) is the constituting and controlling body of the voivodeship. The term of office of the voivodeship assembly (Sejmik) is 5 years, starting from the election day. The voivodeship assembly (Sejmik) is composed of thirty councilors elected in direct elections in voivodeships with up to 2,000,000 inhabitants and three councilors for each subsequent 500,000 inhabitants. (Article 16.2)

The competences of the voivodeship assembly (Sejmik) are defined by law, in particular in Article 18 of the Act on the voivodeship self-government. Resolutions of the voivodeship Assembly are adopted by a simple majority of votes, in the presence of at least half of the statutory composition of the Assembly, in an open or open vote by roll call, unless the provisions of the Act provide otherwise. (Article 19.1)

\section{Scope of activity and tasks of a voivodeship}

The voivodeship self-government defines the voivodeship development strategy in accordance with Article 11 of the Act. When formulating development strategy and implementing development policy, the voivodeship self-government cooperates in particular with: local self-government units from the voivodeship and with economic and professional self-government, government administration - especially with the voivode, other voivodeships, non-governmental organizations and units listed in Article 3 (3) of the Act of 24 April 2003 on public benefit and volunteering (Journal of Laws of 2018, item 450, 650, 723 and 1365 and of 2019, item 37), universities and scientific and research units.

While performing these tasks voivodeship self-governments may also cooperate with international organizations and regions of other, especially neighboring countries. 
The voivodeship assembly (Sejmik of the voivodeship), as a legislative body defines the rules, mode and schedule for the preparation of the voivodeship development strategy. The draft voivodeship development strategy is agreed by the head of the regional water management board of the National Water Holding, Polish Waters in cases concerning building and development of areas of flood risk. The strategy is a local law and is adopted by the Sejmik of a voivodeship as a resolution. This resolution is published in the voivodeship official journal.

According to the Act, in the sphere of public utility, a voivodeship may establish limited liability companies, joint stock companies or cooperatives, and may join such companies or cooperatives.

The voivodeship self-government fulfills voivodeship task a specified by the Acts, in particular: public education (including higher education), health promotion and protection, culture and protection of monuments and care for monuments, social assistance, family support and foster custody system, pro-family stock companies or cooperatives, and may join such companies or cooperatives.

The voivodeship self-government performs tasks of a voivodeship scope specified by the Acts, in particular: public education policy, modernization of rural areas, spatial development, environmental protection, public transport and public roads, physical culture and tourism, protection of consumer rights, defence, public safety, counteracting unemployment and activation of the local labour market, activities in the field of telecommunications, protection of employee claims in case of employer insolvency (Article 14).

Acts may define issues concerning the voivodeship's operation as government administration tasks, performed by the voivodeship board. Acts may also impose on voivodeship an obligation to organize and hold general elections and referendums.

\section{CONCLUSION}

In Poland, there is a three-tier division of territorial self-government: communities, districts and voivodeships. This division allows local and regional authority to perform their functions. It encourages civic activity, which brings benefits to the inhabitants and local communes. On the basis of statutory tasks, local government units are complementary to one another, and in case of threat in a community, district or voivodeship, the decision-making and executive bodies cooperate. The most important legal act regulating the functioning of territorial self-government is the Constitution of the Republic of Poland and the Acts on Community Self-Government, District Self-Government and voivodeship Self-Government.

\section{Conflict of interests}

The authors declare no conflict of interest. 


\section{References}

Levashova, L. (2011), Investments in human capital; in: The organizational change management, edited by J. P. Lendzion, Technical University of Lodz, Lodz, Wydawnictwo Media Press.

Niczyporuk J. (2007), Zadania samorządu terytorialnego, M. Chmaj (red.) Ustrój samorzadu terytorialnego w Polsce, Warszawa, wyd. Wyższa Szkoła Handlu i Prawa im. Ryszarda Łazarskiego w Warszawie.

Stemplewska, L. (2020), Zarządzanie własnym czasem pracy w erze 4.0, Z. Olesiński (red.), Składniki turkusowych organizacji, Warszawa, Wyd. Difin.

Stemplewska, L. (2013), Possibilities of choosing the best employess, in: Quality of the practices in human resources management in organizations of 21st century, edited by: Anna Stankiewicz- Mróz, Lodz, Wydawnictwo Media Press.

Zieliński E. (2013), Administracja rzadowa $i$ samorządowa w Polsce, Warszawa, wyd. Wyższa Szkoła Administracyjno-Społeczna,

Zieliński E. (2004), Samorząd Terytorialny $w$ Polsce, Warszawa, Dom wydawniczy ELIPSA, http://administracja.mswia.gov.pl/adm/baza-jst/843,Samorzad-terytorialny-w-Polsce.html access 21.02.2020).

\section{Legal acts}

Konstytucja Rzeczypospolitej Polskiej z dnia 2 kwietnia 1997 r. Dz. U. z 1997 r. Nr 78, poz. 483, z 2001 r. Nr 28 , poz. 319, z 2006 r. Nr 200, poz. 1471, z 2009 r., Nr 114, poz. 946.

Ustawa z dnia 8 marca 1990 r. o samorządzie gminnym t.j. Dz. U. z 2019 r. poz. 506, 1309, 1571, $1696,1815$.

Ustawa z dnia 24 kwietnia 2003 r. o działalności pożytku publicznego i o wolontariacie Dz. U. z 2018 r. poz. 450,650 , 723 i 1365 oraz z 2019 r. poz. 37.

Ustawa z dnia 20 czerwca 2002 r o bezpośrednim wyborze wójta, burmistrza i prezydenta miasta tj. Dz.U. z 2010 r. Nr 176, poz. 1191 ze zm.

Ustawa z dnia 5 czerwca 1998 r. o samorządzie województwa t.j. Dz. U. z 2019 r. poz. 512, 1571, 1815.

Ustawa z dnia 5 czerwca 1998 r. o samorządzie powiatowym t.j. Dz. U. z 2019 r. poz. 511, 1571.

\section{About the author:}

Barbara BONISŁAWSKA, PhD, Prof. European University of Information Technology and Economics in Warsaw, Dean of Faculty of Management and Administration. Research interests: innovation, innovation activity, management and public administration, self-government, local community

ORCID ID: https://orcid.org/0000-0001-6045-3819 